\title{
The Economic Winners and Losers of Legalized Gambling
}

\author{
Melissa Schettini Kearney \\ Brookings Institution \\ 1775 Massachusetts Avenue, NW \\ Washington, DC 20036-2103 \\ 202-797-6406 \\ mkearney@brookings.edu
}

February 2005

\begin{abstract}
This paper reviews the government role in the legalized gambling sector and addresses some of the major issues relevant to any normative analysis of what the government role should be. In particular, the paper reviews evidence identifying the economic "winners" and "losers" associated with the three largest sectors of the industry: commercial casinos, state lotteries, and Native American casinos. The paper also includes a discussion of the growing internet gambling industry. In addition to reviewing existing literature and evidence, the paper raises relevant questions and policy issues that have not yet been adequately addressed in the economics literature.
\end{abstract}




\section{INTRODUCTION}

In the past three decades, legalized gambling in the United States has grown from a limited activity to one that is extremely commonplace. Gambling in some form is now legal in every state except Hawaii and Utah. Gallup data from 2004 show that two in three Americans report participating in some form of gambling activity in the last 12 months, with state lotteries being the most common. As legalized gambling continues to grow in popularity and prevalence, and new forms of gaming are introduced and expanded, there is much public debate about the costs and benefits of this sector of the economy.

The gambling sector has always been viewed as different from other sectors of the economy. Unlike other industries in which the market is the principal determinant of supply and demand, government decisions have largely determined the size and form of the legalized gambling sector in the United States. For example, in every state that has legalized lottery gambling, the state has declared itself the monopolist provider. In other forms of gambling, federal, state, and local governments determine the kinds of gambling permitted and the number, location, and size of establishments allowed.

One explanation for this view and history of gambling is moral opposition to gambling as a legitimate form of entertainment. Another is concern that unregulated gambling would produce a number of negative effects on society. These include both the negative consequences for gamblers themselves - e.g., financial and family distress caused by problem gambling - and the negative externalities imposed on society, such as increased crime. On the other side of the debate, supporters of legalized gambling recognize the increase in consumer welfare for those who enjoy gambling and participate 
"responsibly". Casino advocates point to potential economic benefits, including job creation and development. Politicians in favor of expanded gambling operations point to the revenue-generating potential for state and local governments of state lotteries and the taxation of casino revenues.

Gross revenues from legalized gambling reached a record-high $\$ 72.9$ billion in 2003. More than 80 percent of this total is accounted for by revenues from commercial casinos, Native American casinos, and state lotteries. Figure 1 shows 2003 gross gambling revenues by industry. Commercial casinos brought in $\$ 28.7$ billion (36.5 percent); state lotteries grossed \$19.9 billion (25.4 percent); and Native American tribal casinos grossed $\$ 16.8$ billion (21 percent). Internet gambling generated $\$ 5.7$ billion in gross revenues. ${ }^{1}$ The remaining $\$ 7.4$ billion is accounted for by pari-mutuel games, charitable games, charitable bingo, card rooms, and legal bookmaking ${ }^{2}$. Figure 2 shows the reported gambling rates among American adults who participated in the annual Gallup Lifestyle Poll conducted in December of 2003. About half of Americans report having bought a lottery ticket in the past 12 months. A third report visiting a casino in the past 12 months, making it the second most common form of legalized gambling.

Each of the gambling industries has a unique history and regulatory structure. Some policy issues are common to all industries in the sector, while others are unique to the particular form of gambling. This article attempts to identify and discuss from an economics perspective the major "winners" and "losers" associated with the three largest

\footnotetext{
${ }^{1}$ Revenues are only available for a global market. Furthermore, the legality of the industry is not firmly established.

${ }^{2}$ Sports betting is legal in only two states: Nevada, through casino sports books, and Oregon, through a state lottery game. The 1999 National Gambling Impact Study Commission (NGISC) report estimated that the scope of illegal sports betting in the United States ranges from $\$ 80$ billion to $\$ 380$ billion annually, making sports betting the most widespread and popular form of gambling in America.
} 
segments of the legalized gambling industry: commercial casinos, Native American tribal casinos, and state lotteries. The article both discusses evidence from recent research and points out relevant issues about which there remains considerable uncertainty. The paper also discusses a relatively new and rapidly growing segment of the industry: internet gambling. This final discussion raises more questions than it answers, as virtually no economic research currently exists on this new sector of the economy.

\section{CASINOS}

Prior to 1978, there were no legal casinos in the United States outside Nevada. In 1978, the jurisdiction of Atlantic City, NJ became only the second jurisdiction in the country to offer casino gambling. By 2003, casinos operated legally in 37 states. ${ }^{3}$ There were 391 commercial casinos operating in 15 states and an additional 356 Native American casinos, operated by 222 tribes, in 30 states. Table 1 lists the number of commercial casinos and Native American casinos by state.

Gross casino revenue in 2003 totaled \$28.7 million, excluding Native American tribal casinos. ${ }^{4}$ This represents a more than three-fold increase since 1990, when casino revenue totaled $\$ 8.7$ billion. Native American, or Indian, casinos are operated by sovereign tribes that are generally exempt from many of the requirements and taxes imposed on traditional business owners. They brought in an additional $\$ 16.2$ billion in 2003. The rapid growth in this industry has been remarkable, as only a handful of tribes operated gaming facilities 20 years ago. Tribes opened their reservations to different games in the late 1970s and continued to open facilities and/or expand existing operations

\footnotetext{
${ }^{3}$ Eadington (1999) provides a discussion of the history and operation of casinos in North America; Evans and Topeleski (2002) provide a review of the history of Native American casinos.
} 
during the 1980s. These facilities often operated in the midst of considerable legal uncertainty and legal battles with states.

In 1988 Congress passed the Indian Gaming Regulatory Act (IGRA) which upheld the sovereignty of tribes over their own development, but also recognized limited regulatory rights on the part of states. The IGRA defines three classes of gambling. Class I includes traditional Indian games, over which states have no jurisdiction. Class II games include bingo and is legal as long as "such Indian gaming is located within a State that permits such gaming for any purpose by any person, organization or entity” and may be overseen both by tribes and by the National Indian Gaming Commission. Class III gambling includes all other forms of gambling, including table games and slot machines. The IGRA specifies that tribes can only offer Class III games when states allow these games elsewhere in the state. So, for example, any tribe in Nevada is eligible to operate a full-scale casino. ${ }^{5}$

There are active constituent groups on both sides of the casino debate. Proponents cite the obvious "pent up" demand among American adults for casino gambling, noting the spectacular rise in gambling participation that has grown alongside the increased availability of casino facilities. In addition to this increase in consumer utility, proponents note potential economic benefits such as job creation and economic development. The

\footnotetext{
${ }^{4}$ Slot machines in Nevada and NJ accounted for \$9.8 million; table games in Nevada and NJ accounted for $\$ 4.3$ million; and riverboat casinos accounted for \$10.2 million of this total (Christiansen Capital Advisors, 2004).

${ }^{5}$ Evans and Topoleski (2002) note that the federal courts have broadly interpreted this provision. They offer the example of Connecticut. At the time of passage of IGRA, the state of Connecticut allowed nonprofit organizations such as church groups to operate "Las Vegas-style" casino nights. The Pequot tribe of Connecticut requested a Class III gaming license, but their request was denied by the state. The Pequots sued in federal court and the court decided in their favor, arguing that statutes allowing "Las Vegas style" gambling in some situations rendered the rules guiding those events civil rather than criminal in nature. The provisions of the Act have been tested, notably in California, New Mexico, and Florida, where tribes have continued to operate casinos after compact negotiations deadlocked.
} 
2004 industry report on Indian Gambling notes that Indian gaming facilities directly supported 240,000 jobs in 2003, paying out $\$ 7.9$ billion in wages. Supporters of Native American casinos in particular point to the potential improvement in economic wellbeing among reservation populations.

On the other hand, opponents anticipate "cannabilized" sales from competing business sectors. Opponents also worry about potential social costs, including increased crime and other problem behaviors. ${ }^{6}$ To the extent that casinos encourage problem gambling, they might lead to increased rates of bankruptcy, suicide, and family problems. An additional source of opposition, often voiced by state legislatures, is that the opening of casinos in a state would reduce state lottery revenue.

\section{$\underline{\text { Impact on surrounding communities }}$}

Much of the economic research investigating the ancillary economic benefits of casinos has focused on riverboat casinos. Riverboat casinos are a uniquely American establishment. They began operating in Iowa in 1991 and quickly expanded throughout the Midwest. By 1998, over 40 riverboat casinos were in operation in Illinois, Indiana, Missouri, and Iowa. Nearly 50 riverboat and dockside casinos were in Louisiana and Mississippi (NGISC, 1999).

There does not appear to be empirical evidence of economic growth as a result of the expansion of riverboat casinos. In terms of generating local tourism, riverboats seem

\footnotetext{
${ }^{6}$ Grinols and Mustard (2004) discuss multiple ways casinos could be expected to alter local crime rates. Casinos might reduce crime directly by improving legal earning opportunities, both through direct wage effects and positive economic development. Conversely, casinos might increase crime by (1) harming economic development by draining the local economy and increasing the incidence of prostitution and illegal gambling-related activities; (2) increasing the payoff to crime by creating opportunities for criminals; (3) increasing the prevalence of problem gambling and thereby increasing the amount of crime generated by gamblers looking to fund their habit; and (4) attracting visitors who are more prone to commit and be victims of crime.
} 
to have been most successful in places such as Galena, Illinois, where the tourism industry was already established. Case studies suggest that the bulk of patrons of riverboat casinos are day-trippers who spend virtually no time at local non-gambling establishments (NGISC, 1999). There thus appear to be few, if any, positive economic spillovers to the local hotel or restaurant industry. In support of the "cannibalization” hypothesis, Siegel and Anders (1999) provide empirical evidence that riverboat gambling in Missouri led to a displacement of revenue from industries that constitute substitutes for gaming activity, such as entertainment and recreation services.

Evans and Topoleski (2002) conduct a rigorous examination of the economic and social impacts of Indian casinos for both Indian tribes themselves and surrounding communities. The authors employ a difference-in-difference empirical approach that compares economic outcomes before and after tribes open casinos to outcomes over the same period for tribes that do not adopt or are prohibited from adopted gaming ventures. Their analysis is based on data for all tribes in the 48 contiguous states for the years 1983, 1989, 1991, 1993, 1995, 1997, and 1999. Based on the circumstances surrounding a particular tribe's gaming operations, the authors define the opening date of an Indiano casino as either the date a tribe added Class III games to its casino or the date of the tribal-state compact signing a new casino into existence.

Their analysis finds mixed results for the impact of Indian casinos on surrounding communities. Their difference-in-difference analysis finds that in counties where an Indian-owned casino opens, jobs per adult increase by about five percent of the median value. The authors also look at mortality as an outcome. Theoretically, the availability of casino gambling may increase substance abuse and suicidal thoughts and so could 
increase mortality rates. On the other hand, to the extent that casino gambling increases employment opportunities and income, improved economic well-being could lead to a decrease in mortality. Their data suggest that the opening of an Indian casino in a county leads to a 2 percent reduction in county-level mortality rates. However, the authors identify substantial negative effects as well - bankruptcy rates, violent crimes, and auto thefts and larceny each increase in the surrounding community by 10 percent.

Grinols and Mustard (2004) empirically investigate the relationship between casinos and crime rates using county-level crime data on the 7 FBI Index 1 offenses (robbery, aggravated assault, rape, murder, larceny, burglary, and auto theft) from 1977 to 1996 . Their paper utilizes the quasi-experiment created by casino openings to identify a causal relationship. ${ }^{7}$ Their study includes all 3,165 counties in the U.S. and the period observed includes the introduction of casinos in all counties except those in Nevada. Their sample of casinos includes land-based, riverboat, and tribal-owned casinos.

The authors find a sharp increase in most crimes after the introduction of casinos. Their results suggest that the effect on crime is low shortly after a casino opens, and grows over time. They calculate that roughly eight percent of crime in casino counties in 1996 was attributable to casinos, costing the average adult $\$ 75$ per year. In addition, they confirm that border counties also experience increased crime rates, which suggests that casinos increase aggregate crime, as opposed to merely shifting crime from one county to another.

Of all the potential social costs of gambling, the link between casinos and crime has received the most research attention. It is very difficult to identify a causal link from 
casinos to problem and pathological gambling and associated consequences. The 1999

Gambling Impact and Behavior Study by Gerstein et al., prepared for the National

Gambling Impact Study Commission (NGISC) ${ }^{8}$, yields some evidence suggesting that the opening of casinos has negative social impacts. Using criteria developed by the American Psychiatric Association, the authors estimate that about 2.5 million adults are pathological gamblers and another 3 million adults are considered problem gamblers. ${ }^{9}$ They find that such gamblers are more likely than other gamblers or nongamblers to have been on welfare, declared bankruptcy, and to have been arrested or incarcerated.

Furthermore, their study finds that the availability of a casino within 50 miles (versus 50 to 250 miles) is associated with about double the prevalence of problem and pathological gamblers. However, it is not clear that these associations reflect a causal link from casinos to problem behaviors.

Though data on family problems, crime and suicide are available, tracking systems generally do not collect data on the causes of these incidents, so they cannot be linked to gambling. It is particularly difficult to identify a causal link between gambling and other problems, as pathological gamblers often have other behavioral disorders (GAO, 2000, p 3). Additional data and research establishing the causal link between

\footnotetext{
${ }^{7}$ See Grinols and Mustard (2004) for a discussion of weaknesses in the previous literature, which has tended to focus on small samples and isolated case studies and/or has made no attempt to deal with issues of omitted variable bias.

${ }^{8}$ Congress created NGISC in 1996 to conduct a comprehensive study of the social and economic impacts of gambling the United States. The research included two national surveys of U.S. adults and youths; a survey of patrons at 21 gambling facilities; case studies in 10 communities; and detailed analyses of a 100community sample to determine the economic impact of casino gambling.

${ }^{9}$ Clinically, the American Psychiatric Association (APA) classifies pathological gambling as an impulse control disorder and describes 10 criteria to guide diagnoses, ranging from "repeated unsuccessful efforts to control, cut back, or stop gambling" to committing "illegal acts such as forgery, fraud, theft or embezzlement to finance gambling." "Problem gamblers" experience a wide range of adverse consequences from their gambling, but fall below the threshold of at least five of the ten APA criteria used to define pathological gambling.
} 
casino availability and the incidence of personal bankruptcies, suicide, divorce, and other costly behaviors is needed.

\section{Impact on Native American tribes}

An explicit goal of the IGRA was to promote "tribal economic development, selfsufficiency, and strong tribal governments.” Tribes frequently refer to casinos as the "new buffalo,” meaning the new source of economic sustenance for their communities. The tribes point to repaired infrastructure; diversifying economies; rising employment; augmented health, housing, education, and social budgets; greater indigenous language retention; and generally renewed community vitality (Taylor, Krepps, and Wang, 2000). Evans and Topoleski (2002) find that four years after tribes open casinos, tribal population is up by 12 percent and tribal employment has increased by 26 percent, resulting in an increase in tribal employment-to-population ratios of five percentage points (12 percent). In addition, the data suggest a 14 percent reduction in the fraction of adults in the tribe who are working but poor. Furthermore, the data offer no evidence that prior levels or changes in economic conditions determine which tribes adopt gaming. This latter finding bolsters confidence in a casual interpretation of the estimated effects of a tribal casino on population and employment.

While the empirical evidence suggests that Indian tribes are, on average, clearly "winners" in this venture, the question remains as to whether this is the most efficient policy to improve economic circumstances on reservations. As Evans and Topoleski note, “After 130 years of reservation life, Native Americans on reservations were among the poorest people in this country, so the preceding policies for economic independence were not working. Because the current program seems to be generating jobs does not 
necessarily mean that granting reservations a monopoly in a particular industry is a desirable policy (p. 49).”

\section{Impact on public revenue}

Casino businesses are subject to taxation and therefore have a direct impact on public revenue. Maximum tax rates on gross gaming revenues in American casinos range from 6.25 percent in Nevada to 35 percent in Illinois. Taxes on casinos are not an important source of public sector revenues for most states in the United States; only Nevada is heavily dependent on tax revenue from casino gaming. Non-Indian casinos paid over $\$ 2$ billion in taxes to states on gaming revenues in 1997, compared to state lottery revenues of approximately $\$ 10$ billion in the same year (Eadington, 1999, p. 187).

By law, states cannot tax the profits of tribal businesses. But in some states (e.g., Connecticut, Michigan, Wisconsin, California, and New Mexico), tribes have agreed to make annual payments to state governments. These fees are typically payments for the monopoly rights the state has granted the tribe to provide certain forms gambling. In 2003, tribes contributed over $\$ 759$ million to state and local governments via various forms of revenue-sharing (Meister, 2004, p.1). Table 2 lists tribal contributions to state and local governments by state. As shown, there is tremendous variability across states. The two tribes that operate Mohegan Sun and Foxwoods in Connecticut alone account for over half of these payments.

Casinos might indirectly affect public revenue as well. Insofar as casinos generate additional business income, they might indirectly increase other forms of tax revenue. Insofar as they cannibilize sales from other businesses, they might decrease net tax revenue. Anders, Siegel, and Yacoub (1998) find that as a result of the introduction of 
two Indian casinos into Maricopa county, Arizona in 1993, employment and retail sales in the restaurant and bar sectors declined. Popp and Stehwien (2002) estimate a similar model to examine the effect of New Mexico’s eleven Indian casinos on gross state tax receipts using quarterly data from 1990 to 1997. They also find a negative effect of Indian casinos on state sales tax revenues; the introduction of a single Indian casino is found to be associated with a one percent decrease in county tax revenues, but the introduction of a second Indian casino in the county if found to reduce sales tax revenue by more than 6 percent. While suggestive, these analyses are limited in scope and their results do not necessarily generalize to the experiences of other states. Additional research on the link between casino gambling and state sales tax revenue is warranted.

Casinos could also cannibalize sales from state lottery operations. Three studies offer evidence suggesting that they do. Siegel and Anders (2001) investigate the relationship between Indian casinos and state lottery revenue in Arizona. The authors’ empirical analysis finds that a 10 percent increase in the number of slot machines is associated with a 2.8 percent decline in lottery sales. Elliott and Navin (2002) examine the impact that the introduction of riverboat casinos between 1989 to 1995 has on state lottery sales. They find that riverboat gambling expenditures have a negative and statistically significant impact on state lottery revenues. Fink and Rork (2003) build on this work by examining data on 48 states from 1988 to 2000 and using actual tax receipts from all forms of commercial casinos. Also, like Elliott and Navin (2002), the authors perform a Heckman two-step selection correction, but in the first stage the authors model the adoption of a commercial casino, rather than the adoption of a state lottery. Their analysis finds a strong cannibalization of state net lottery revenue by commercial casino 
tax revenue. Specifically, they find that an increase of $\$ 1$ in commercial casino revenues reduces net lottery revenues by $\$ 0.56$.

\section{$\underline{\text { Unresolved issues }}$}

The weight of the empirical evidence suggests that casinos do in fact impose negative social costs on surrounding communities, most notably, an increased prevalence of property and violent crime. Studies of riverboat casinos do not find evidence of positive economic spillovers, though Evans and Topeleski’s study of Indian casinos find some evidence of increased employment in the surrounding community. Future research is needed into the nature of the heterogeneity of effects. Casinos vary greatly in size and scope. Facilities in the top ten Indian gaming states accounted for 83 percent of total industry revenue. ${ }^{10}$ Riverboat casinos are smaller than Las-Vegas-style casinos. It is reasonable to expect that a very large casino, such as Foxwoods in Connecticut, might increase both crime and employment in the county, while a small riverboat casino with less of a tourist draw might lead to no change in aggregate crime rates or net job creation. A better understanding of how the economic and social benefits and costs vary with the size, scope, and nature of a gaming establishment would have important policy implications.

The distributional impacts are also not well-understood. Native Americans on reservations seem to be big winners of the tribal gaming movement with increased reservation population and employment. But who are those deciding to re-migrate to tribes or stay on the reservation? Are the Native American beneficiaries those who would have been economically successful elsewhere? Surrounding communities seem to win in

\footnotetext{
${ }^{10}$ From highest to lowest, these states are California, Connecticut, Minnesota, Arizona, Wisconsin, Michigan, Washington, Florida, New Mexico, and New York (Meister, 2004, p.1).
} 
terms of job creation and lose in terms of increased bankruptcy and crime. But who are getting new jobs? And who are the victims of crime?

In addition, future research should consider the optimal design of state-tribe compacts. The characteristics of tribal-state gaming compacts vary widely from state to state. Most compacts restrict the types of games, some restrict the size and number of casinos tribes can run, and other specify annual payments to states. Whether states design tribal compacts such that the revenue payments exceed foregone tax revenue is ultimately an empirical question that depends crucially on what gaming and tax revenue from commercial-casinos would be. Furthermore, the current legal environment prevents state and local governments from imposing a tax on tribal gaming ventures that would force them to internalize the costs of negative externalities on the surrounding community. Though some tribes do pay fees as specified in their compact, there is no standard practice across states. $^{11}$

And finally, a major issue common across all forms of legalized gambling is the efficiency costs associated with the established market structure. In many states, the nature of agreements between states and Native American tribes grants tribes monopoly power over the provision of casino-style gambling. Any explicit limitation on entry into a market imposes a deadweight economic loss on society. Future research should investigate the consequences of this market structure for consumers.

\footnotetext{
${ }^{11}$ Thompson and Schmidt (2002) examine the Native American casino experience in the state of Wisconsin. They estimate that tribal casinos currently pay the state of Wisconsin $\$ 24.7$ million per year, just over 2 percent of gaming revenues. They calculate that a similar-sized business would be paying state and local business and property taxes of roughly $\$ 90$ million per year. They note that these taxes offset the costs of actual services businesses receive, including the right to offer a business activity with limited competition due to licensing restrictions and franchise requirements.
} 


\section{STATE LOTTERIES}

Lottery ticket sales totaled $\$ 41.4$ billion in 2003, yielding gross revenues for states of $\$ 19.9$ billion (Christiansen Capital Advisors, 2004). This represents annual average sales of $\$ 212$ per adult living in a lottery state, or $\$ 372$ per household nationwide. By 1998, every continental state without a lottery bordered at least one state with one, making out-of-state lottery gambling feasible for a sizeable number of adults. Nonetheless, participation in lottery gambling and average annual lottery expenditures are significantly and substantially higher among residents of lottery states than nonlottery states (Kearney, forthcoming).

The era of the modern state lottery began in 1964 in New Hampshire. ${ }^{12}$ Following New Hampshire’s lead, New York and New Jersey soon introduced their own state lotteries. The spread of lotteries across the country primarily followed a geographical pattern, spreading first across the Northeast, then to the West, and finally to the Midwest and South. ${ }^{13}$ In 2004 the state of Tennessee became the $39^{\text {th }}$ state, in addition to the District of Columbia, to operate a state lottery. In each case the state ended its former prohibition of lotteries and established a state agency as the sole provider of lottery products. Table 1 lists implementation dates.

Every state that currently has a state lottery offers instant lottery games. Instant games - typically in the form of scratch-off tickets - were first introduced in 1974 as a product offered by the Massachusetts State Lottery. These games offer consumers instant feedback on whether they have won and, if the prize won is less than a designated

\footnotetext{
12 See Clotfelter et al. (1999) for a discussion of the history and operation of state lotteries.

${ }^{13}$ Much anecdotal evidence suggests that cross-border lottery sales place pressure on neighboring states to implement their own state lottery. Empirical evidence of the positive effect of border competition on lottery adoption decisions is found in Berry and Berry (1990) and Alm, Mckee and Skidmore (1993).
} 
amount, players can cash in on their winnings immediately. Instant tickets typically cost one, two, or five dollars, but states have recently started offering higher-priced instant tickets with opportunities to win multi-million dollar prizes. As shown in Table 2, sales on instant lottery games account for almost half of all state lottery revenue.

There is substantial public controversy surrounding the use of lotteries as a means of raising public funds. Opponents argue that state lotteries prey on minorities and the poor and that spending on state lotteries displaces consumption and savings. Some worry that governments are "tricking” people with a "sucker’s bet," exploiting misinformation on the part of consumers. Supporters of state lotteries counter that people from all demographic groups play the lottery. They argue that people demand gambling products and a state lottery capitalizes on that demand by providing a product that substitutes for other forms of gambling. Some characterize lottery sales as voluntary purchases of entertainment goods.

\section{Distributional impacts}

A number of studies have investigated the demographic predictors of lottery gambling and have tended to find that, on average, state lottery products are disproportionately consumed by the poor. (Recent examples include Worthington (2001), Hansen (1995), and Scott and Garen (1993). Miyazaki et al. (1998) and Clotfelter and Cook (1989) provide a review of earlier studies.) Kearney (forthcoming) reviews microlevel evidence on who plays the lottery from the 1998 National Survey on Gambling conducted by the National Opinion Research Council (NORC) under contract with the NGISC. The data reveal the following general trends. First, lottery gambling extends across races, sexes, and income and education groups. Second, black respondents spend 
nearly twice as much on lottery tickets as do white or Hispanic respondents. The average reported expenditure among blacks is \$200 per year, \$476 among those who played the lottery last year. Black men have the highest average expenditures. ${ }^{14}$ Third, average annual lottery spending in dollar amounts is roughly equal across the lowest, middle, and highest income groups. This implies that on average, low-income households spend a larger percentage of their wealth on lottery tickets than other households.

Interestingly, the regressivity of the state lottery appears to vary across lottery products. Low-income lottery players are more likely than other lottery players to bet on instant games. Among NORC survey respondents who report playing the lottery, 38 percent of those in the lowest-income third report that they purchased an instant ticket the last time they played the lottery, compared to 27 and 19 percent of players in the middleand highest-income third. Higher-income players are more likely to have purchased a ticket on a jackpot lotto game - 56 percent of those in the highest-income third, 49 percent in the middle group, and 39 percent in the lowest-income third. The NORC survey also asks respondents about their favorite state lottery game. Instant games are the most common reported favorite among those in the lowest-income third, while jackpot lotto games are by far the most common stated favorite among those in the higher income categories.

Oster (2004) examines data on Powerball lotto sales to analyze how regressivity varies with jackpot size within a single lottery game. She evaluates sales data by zip code

\footnotetext{
${ }^{14}$ In order to develop estimates of annual lottery expenditures, Kearney uses a set of assumptions used by Clotfelter et. al. (1999), who calculate that estimates of national expenditures based on the NORC (1998) survey and this set of assumptions amount to only 86 percent of recorded sales. The reader should keep in mind that actual expenditures must therefore exceed reported amounts. That being said, the fifteen black male high-school dropouts in the sample report average annual expenditures over $\$ 1,000$; among the ten who participated in lottery gambling during the year, annual expenditures are over \$2,000. In the 1999 Current Population Survey March file, mean income among this demographic group is \$10,400.
} 
for 199 lottery drawings in the state of Connecticut in which the prize varied from $\$ 10$ million to $\$ 150$ million. The data indicate that the lottery is less regressive at higher jackpot levels. One explanation could be that higher jackpots increase the "fun" of lottery gambling and richer individuals have a higher threshold for entry. Alternatively, richer individuals might have a better understanding of the fact that the expected value of a gamble increases with the jackpot size, and such individuals are more responsive to the effective price of a lottery gamble.

The finding that regressivity varies with product characteristics has important policy implications. A state could mitigate the regressive - and potentially addictive nature of its state lottery products by moving away from instant games. Instant tickets are highly lucrative for states, but are the product that particularly appeals to low-income consumers and, potentially, to problem gamblers. However, states appear to be moving in exactly the opposite direction by introducing higher-priced instant games. For example, in 2004 Connecticut introduced a \$20 scratch-off ticket and the state has plans to introduce a $\$ 30$ ticket in the summer of 2005. Some state lotteries, for example California and West Virginia, have recently introduced "Video Lottery Terminals (VLTs)", which are stand-alone machines akin to the stand-alone legal "electronic gambling devices (EGDs)" offering video poker and video keno in some truck stops and restaurants, for example, in South Carolina. These machines are particularly controversial. Gambling experts have noted that such machines potentially create dependency among gamblers and have called them the "crack cocaine of gambling” (NGISC, 1999, p.2-6).

\section{$\underline{\text { Impact on consumer behavior }}$}


Does spending on lottery tickets crowd out savings and consumption, or merely other forms of gambling? Analyzing multiple sources of micro-level data, Kearney (forthcoming) finds that household lottery spending is financed entirely by a reduction in non-gambling expenditures. ${ }^{15}$ The main analysis examines household expenditure data from the 1982 to 1998 Interview Survey files of the Bureau of Labor Statistics (BLS) Consumer Expenditure Survey (CEX). During this time 21 states implemented a state lottery. The empirical analysis exploits the variation across states in the timing of state lottery introduction to compare the change in household expenditures among households in states that implement a lottery to the change among households in states that do not. The introduction of a state lottery is associated with an average decline of \$46 per month, or 2.4 percent, in household non-gambling expenditures. This figure implies a monthly reduction in household expenditures of \$24 per-adult, which compares to average monthly lottery sales of $\$ 18$ per lottery-state adult.

Among households in the lowest income third of the CEX Interview sample, nongambling expenditures are reduced by an average of 2.5 percent, 3.1 percent when the state lottery offers instant games. Furthermore, the data demonstrate a statistically significant reduction in expenditures on food eaten in the home (2.8 percent) and on home mortgage, rent, and other bills (5.8 percent). The data do not indicate which households purchase lottery tickets, so these average effects do not account for the fact that a substantial fraction of households do not engage in lottery gambling. For

\footnotetext{
${ }^{15}$ These results are not necessarily inconsistent with the finding reported in Fink and Rork (2003) that casino revenues partially crowd-out lottery sales. A state lottery bet is much more expensive in expected value terms than a dollar gambled at a casino. Therefore, it is possible that the introduction of a state lottery would not cannibalize casino revenues, even if the introduction of a casino would cannabilize lottery revenues.
} 
households that do purchase lottery tickets, the decline in non-gambling expenditures must therefore be considerably greater.

In order to determine whether the shift in household consumption from nongambling expenditures to lottery tickets is consumer-welfare enhancing, we must know whether lottery gamblers are rational, informed consumers, or whether, as some claim, the state is indeed taking advantage of misperceptions and mistakes on the part of consumers. There is evidence that in some ways, consumers, on average, appear to be making sound decisions with regard to lottery purchases, but that in other ways, they are not.

Lottery gambling is part investment, as consumers are making choices over risky assets, and it is part entertainment. Assuming that the entertainment and pecuniary components of the lottery gamble are separable, maximizing behavior predicts that consumer demand for lottery products should depend positively on its expected return, holding constant game characteristics. To evaluate whether this prediction holds, Kearney (forthcoming) analyzes weekly sales and characteristics data from 91 lotto games from 1992 to 1998 . The analysis suggests that sales are positively driven by the expected value of a gamble, controlling for higher-order moments of the gamble and non-wealth creating characteristics. This finding is robust to alternative specifications, including controlling for unobserved product fixed effects. The data also reveal that consumers respond to nonwealth creating, "entertaining” game features. Together, these two findings suggest that consumers are at least partly - and potentially fully - informed, rational consumers. It is consistent with these findings to claim that consumers derive an entertainment equal to 
the price of the gamble (one minus expected value), and then, insofar as they are making investments, they are informed evaluators of gambles.

There is also evidence of mistaken investment decisions on the part of state lottery gamblers. Clotfelter and Cook (1993) and Terrell (1994) - provide evidence of the “gambler’s fallacy” among lottery players. The "gambler’s fallacy” is the mistaken notion that the second draw of a signal will be negatively correlated with the first draw. For example, if a slot machine has not won in a while, some gamblers believe it is "due" to win, or vice versa. Using data from the Maryland and New Jersey numbers games respectively, they find that the amount of money bet on a particular number falls sharply after the number is drawn and that it gradually returns to its former level after several months.

Guryan and Kearney (2005) investigate whether consumers respond to the location of a winning lottery ticket. The sale of a winning lottery ticket at a store does not affect the likelihood that the retailer will sell a winning ticket in the future. Therefore, if fully informed consumers treat lottery tickets as purely financial assets, then store-level sales should not respond to such an event. However, weekly sales data from the full population of lottery retailers in the state of Texas reveal that between 2000 and 2002 retailers who sell a winning jackpot ticket experience relative increases in ticket sales of the winning game between 12 and 38 percent the following week, and that the sales response increases in the size of the jackpot. The random assignment of winning tickets to stores, conditional on contemporaneous sales, allows this subsequent increase to be interpreted as causally related to the sale of the winner. To the extent that the sales response reflects a belief that the store is "lucky", consumers are exhibiting irrational 
perceptions of randomness. If lottery consumers misperceive the probability of winning, they are in effect responding to the wrong price, and must forgo other consumption in exchange for the lottery tickets. Furthermore, the authors find that the increase in sales experienced by the winning vendor increases with the proportion of the local population comprised of high school dropouts, elderly adults, and households receiving public assistance. Therefore, if the response does reflect a mistaken notion, economicallydisadvantaged groups appear most likely to espouse it.

The aggregate effect of state lotteries on consumer welfare is ambiguous. For those rational, informed consumers who derive entertainment value from lottery gambling or who benefit from the easy access to gambling, consumer utility is clearly

increased. For those who are irrational or misinformed, welfare is potentially harmed. ${ }^{16}$

\section{Impact on state government revenue}

All states use the profits from the state lottery operation as a source of revenue. On average, a dollar wagered on a state lottery game returns about 50 cents to players in the form of prizes and 30 cents of profit to the state, with the rest covering administrative costs. Lotteries' contributions to state budgets are actually quite modest. In 2001, the contribution of state lottery funds to total own-source general revenues averaged 0.71 percent across the 37 states with lotteries. Contributions ranged from 0.28 percent in Montana to 8.27 percent in Delaware (U.S. Bureau of the Census, 2004).

\footnotetext{
${ }^{16}$ A consideration of the welfare gains or losses associated with winning the lottery is outside the scope of this discussion. Imbens, Rubin, and Sacerdote (2001) conduct an original survey of people playing the lottery in Massachusetts in the mid-1980s to estimate the effect of unearned income on economic behavior. They find that "unearned" lottery prizes reduce labor earnings, with a marginal propensity to consume leisure of approximately 11 percent. They also find that after receiving about half their prize, individuals saved about 16 percent. Some anecdotal evidence suggests that winners of exceptionally large prizes experience personal hardships, including divorce and depression, but to the best of my knowledge, there is no compelling research on this point.
} 
Of the 41 state lotteries, revenue from eleven is contributed entirely to general funds and revenue from 18 is earmarked in total or in part for education. Other uses range from the broad (parks and rec, tax relief, economic development) to the narrow (Mariner's Stadium in Washington and police and fireman pensions in Indiana). Given the fungibility of money, many economists question whether earmarked money actually increases spending on the intended category of expenditures. However, there has been a sizeable public finance literature documenting the so-called "flypaper effect", whereby money "sticks where it hits". Recent work has investigated whether this appears to be true for earmarked lottery revenue.

Evans and Zhang (2002) investigate whether the 16 states that earmark lottery revenues for K-12 education see increases in spending in this category. They conduct three empirical tests. First, they examine states that switched the allocation of lottery profits from the general fund into public education during the sample period of 1978 to 1998. Second, for the nine states that have always earmarked lottery profits for K-12 education, they examine whether period-to-period changes in lottery profits correlate with period-to-period changes in state spending on education, controlling for state and year effects and state-specific time trends. Third, they utilize a two-state least squares approach to estimating the relationship between lottery profits and K-12 spending using the introduction of lotto games and video lotteries as instruments for lottery profits.

The authors find very similar results across the three approaches. A dollar increase in earmarked revenues contributes an additional 60 to 80 cents in K-12 education expenditures. In comparison, in states that deposit funds into the general fund, each dollar of lottery profit increases school spending by 40 to 50 cents; in states that 
earmark lottery profits for other uses, a dollar of lottery profit increases school spending

by only 30 cents. In a contemporaneous paper utilizing a similar methodology, Novarro

(2002) also finds that the earmarking of lottery revenue to education does in fact lead to substantial increases in spending on education. She finds that a dollar of lottery profits earmarked for education increases current educational spending by roughly 36 cents more than a non-earmarked dollar and by 60 cents more than a dollar earmarked for other uses. $^{17,18}$

\section{$\underline{\text { Additional issues }}$}

First, in addition to the distributional consequences of consumer spending on state lotteries, the distributional consequences of state lottery revenue need to be investigated. For example, in those states that earmark lottery revenue for education, what demographic groups appear to benefit from any increase in education spending?

Stranahan and Borg (2004) investigate the redistributive nature of the lottery-funded merit-based scholarship in Florida. They find that high socioeconomic (SES) households receive a net program benefit while low SES households incur a net program loss. This finding reflects the fact that lower SES households tend to spend more on lottery tickets but are less likely to receive scholarships. More general research on the full distributional consequences of state lottery programs is needed.

Second, the discussion of consumer consequences of state lotteries has focused on the effects for the consumers themselves. An additional concern is whether the individual

\footnotetext{
${ }^{17}$ Several earlier papers, including Mikesell and Zorn (1986), Borg and Mason (1988, 1990), Borg et al. (1991), and Spindler (1995), conclude that the earmarking of lottery funds to education does not increase education spending. However, the empirical analyses of these papers have methodological limitations that prohibit a causal interpretation of the results.

${ }^{18}$ There is the additional budgetary question of the impact of state lotteries on other state tax revenue. Recent work by Fink, Marco, and Rork (2004) suggests that sales and excise tax revenue decreases with increased lottery sales.
} 
gambler makes choices that harm those around him, in particular, other members of his household. Traditionally, economists have considered the family or household as a single unit that maximizes a common objective function subject to the family budget constraint. But recent evidence, in particular from the development economics literature, suggests that the household is a collective, not a unitary, entity and that expenditures depend in part on who controls the household income. If the members of the household do not share a common utility function, any increase in gambling expenditures might come at the expense of the well-being of those not in control of the household finances. More research on the intra-family externalities associated with lottery gambling is needed. More generally, additional research is needed on associated costly behaviors, including, for example, the incidence of financial distress and bankruptcy.

Third, issues related to market structure should be considered in any normative analysis of the operation of state lotteries. As has been noted above, state lotteries operate as state monopolies. The state's take is much larger than the house advantage (defined as percentage the house takes out of a dollar on average) found in casinos. ${ }^{19}$ Competition from private lotteries or casinos could directly benefit consumers by compelling state lottery commissions to increase the payout on lottery gambles. Research into this issue is warranted.

A related issue is market competition across states. Observers have noted a "race to the bottom" among states to offer lottery games. This pressure manifests itself not only in the decision to implement a state lottery, but also to offer higher-priced instant tickets, introduce Video Lottery Terminals, and participate in bigger games, such as Powerball. 
Brown and Rork (forthcoming) present evidence suggesting that cross-state competition benefits consumers; using data from 1967 to 2000, they find that a 10 percent increase in a neighboring state's lottery payout is associated with a 5 percent increase in own-state lottery payout. Tosun and Skidmore (2004) examine data on lottery sales for all 55 counties in West Virginia over the period 1987 to 2000. Their analysis suggests that lottery game adoptions in bordering states have statistically and economically significant negative effects on West Virginia border county lottery sales. Garrett and Marsh (2002) present evidence that cross-border lottery shopping leads to significant reductions in lottery revenue in the state of Kansas. More research into the nature and effects of state competition is warranted.

Finally, an important policy consideration in the operation of state lotteries is advertisting. In 2002, state lotteries spent about \$466 million to advertise, roughly one percent of total sales (LaFleur). Policy analysts ought to consider who is targeted by state advertising campaigns and whose gambling behavior is affected. A main justification for the state's role as monopoly provider of lotteries is "protection” of the public. But if states are setting the price of a lottery gamble (where price is defined as the ticket price minus the expected return) relatively high, innovating with products that are deemed most regressive and addictive, and aggressively advertising their product, then it what sense is the state "protecting” the consumer? And if the state's role is not protective, but rather profit-driven, wouldn’t consumer welfare be enhanced by allowing private competitors to enter the industry?

\footnotetext{
${ }^{19}$ Eadington (1999) presents the estimated house advantage for select casino games: craps $1.41 \%$; blackjack .50\%; roulette (American) 5.26\%; roulette (European) 2.70\%; baccarat 1.25\%; pai gow poker $2.50 \%$; video poker $2 \%$; slot machines $5 \%$; and keno $28 \%$.
} 


\section{INTERNET GAMBLING}

The double-digit growth in legalized gambling revenues experienced during the 1980s and 1990s now seems to be limited to three sectors: tribal gaming, legal sports betting, and Internet gambling. From 2002 to 2003, revenue from tribal gambling grew by 16.23 percent and revenue from Nevada sports betting grew by 11.98 percent. Internet gambling saw an increase in revenue of 42 percent (Christiansen Capital Advisors, 2004).

Since the emergence of internet gambling in the mid-1990s, Internet gambling operators have established approximately 1,800 e-gaming web sites in locations outside the United States. Though precise data is not readily available, estimates of the size of the online gambling industry are generally around $\$ 5$ billion (GAO 2002). According to Christiansen Capital Advisors LLC, the annual revenue of online operators has grown from \$1.2 billion in 1999 to \$5.7 billion in 2003 (Hahn and Tetlock, 2004). Multiple sources report that U.S. customers account for roughly half of the total operating revenues from Internet gambling (GAO 2002).

ComScore, a private company that uses data collection technology to measure Internet audiences, reports that in December 2001 there were 13.6 million unique visitors to gambling sites. One might conjecture that Internet users represent a more economically-advantaged slice of the population and that this type of gambling, unlike state lottery gambling, is therefore concentrated among higher-educated or higher-income consumers. On this point, ComScore (2002) notes that Internet surfers with a household income of less than $\$ 25,000$ represent 11 percent of the overall on-line population and 13 percent of visitors to gambling sites. It would be interesting to know what share of online gambling revenue is accounted for by bets placed by consumers in this income group. In 
other words, do the "heavy" bettors tend to be concentrated among low-income Internet users?

The major policy issue regarding Internet gambling is the optimal level and form of regulation, or alternatively, taxation. In general, gambling is a matter of state law, with each state determining whether individuals can gamble within its borders and whether gaming businesses can legally operate there. Six states have explicitly prohibited Internet gambling: Illinois, Louisiana, Michigan, Nevada, Oregon, and South Dakota. Since Internet gambling typically occurs through interstate or international means - with a web site located in one state or country and the gambler in another - federal law is used to protect the states from having their laws circumvented. The Department of Justice has investigated and brought charges against at least 20 Internet gambling operators on charges of violating the Federal Wire Act of 1961. This Act stipulates that it is illegal to use "wire communications" to place or assist with placing bets or wagers; courts have disagreed on the applicability of certain provisions of the statute to Internet gambling (Hahn and Tetlock, 2004). Federal prosecutors have also pressured American companies to stop providing services to offshore gambling sites. Google, Yahoo, and Lycos stopped advertising on the sites in April 2004 after significant pressure from federal prosecutors. Many American credit card companies, e.g. Visa and Mastercard, no longer allow their credit cards to be used for Internet betting ${ }^{20}$ (GAO, 2002; Hahn and Tetlock, 2004).

To determine what degree and form of regulation is optimal requires an understanding of the costs and benefits of the existence of a well-functioning Internet

\footnotetext{
${ }^{20}$ Efforts to restrict the use of credit cards for Internet gambling can be circumvented by cardholders' use of on-line payment providers to pay for gambling activities. Moreover, as banks increasingly choose to restrict the use of credit cards for Internet gaming, Internet gambling sites are expected to emphasize newer forms of payment, such as e-cash, that could eventually replace credit cards. (GAO, 2002)
} 
gambling market. Again, social welfare is enhanced insofar as the introduction of this good increases consumer utility. Internet gambling is exceptionally inexpensive, imposing virtually no transportation or transaction costs on consumers. On the other hand, an increase in youth gambling, gambling addiction, and crime are all potential social costs of the rise in Internet gambling. As the Internet provides the luxury of anonymity and privacy, Internet gambling might be more problematic - relative to traditional forms of gambling - in terms of attracting youth and problem gamblers. The unique features of Internet gambling also lead to a heightened potential for credit card or other fraud. Empirical evidence on all these points is lacking.

The availability of internet gambling might also have negative effects on worker productivity. ComScore (2002) finds that people spent a total of 274 million minutes on gambling sites, with visitors spending 20.2 minutes on average per month on the sites. This compares to 9.8 average monthly minutes for visitors to health-information sites, 35.8 minutes for travel sites, 52.8 minutes for general news sites, and 62.0 minutes for sports sites. They report that one-third of gambling visits occur at work.

An important consideration is how internet gambling will affect traditional forms of gambling. On the one hand, internet gambling might cannibalize state lottery sales and casino revenue. On the other hand, some gamblers who might not otherwise purchase a lottery ticket or travel to a casino will indulge in this anonymous, virtually costless form of gambling and learn that they like gambling. Internet gambling could thus encourage participation in other forms of gambling. A related issue is whether the advertising of online gambling sites has spillover effects - either positive or negative - to brick-andmortar gambling establishments. ComScore (2002) reports that the online casino industry 
ranks as the fifth largest online advertiser among 138 industry segments. Online advertising by virtual casinos increased 170 percent between December 2000 and 2001, from 911 million advertising impressions to 2.5 billion. Does this internet advertising increase the total market demand for gambling products or merely increase the market share of online betting sites?

There is also a potential interaction between the regulations imposed on traditional forms of gambling and the growth in internet gambling. As internet gambling is largely provided by offshore companies outside the reach of American gambling regulations, heavier regulations of off-line gaming establishments might encourage people to shift to these gambling outlets. The reverse is also true - increased regulation of internet gambling might increase the revenues of other gambling ventures, or lessen the potential decrease. An additional issue, noted by Hahn and Tetlock (2004), is that any benefits of regulation ought to be weighed against the cost of discouraging the existence of gambling and information markets with useful economic purposes, such as the Iowa Electronic Markets, which track economic and political events such as elections.

\section{Conclusion}

This paper has attempted to review the most compelling empirical evidence about the social and economic costs and benefits associated with the three largest industries in the legalized gambling sector - commercial casinos, Native American casinos, and state lotteries. The obvious economic winners are the businesses themselves and the consumers who benefit from consumption of their product. Very little work, if any, has been done to document the increase in consumer utility associated with the increased availability of legalized gambling. Most of the research reviewed here on casino 
gambling has focused on documenting the impacts of casinos on surrounding communities, the impact of tribal casinos on the affected reservation population, and the impact on net public revenues. The work reviewed on state lotteries has tended to investigate the effect on consumer behavior and public revenue.

Many important economic issues remain to be studied and additional rigorous research is needed. The issue of substitutability across gambling types has been widely addressed in the literature, but is still not entirely understood. There appears to be some evidence of substitution, but recent history suggests that Americans gamble in increasing numbers and increasing sums. How much of an increase in gambling will we experience before reaching an equilibrium level? Is there an optimal level? Issues related to market structure, including the optimal level of regulation, need to be addressed. How much does regulation of one gambling industry drive demand for another? Is regulation an effective tool for encouraging less costly or more beneficial forms of gambling? What are the economic costs associated with the monopoly status granted to states over lotteries and, in many states, to Native American tribes over casinos? The ultimate policy question in the debate over legalized gambling is from a social welfare point of view, to what extent the increase in consumer utility and public revenue offsets the associated social costs. This piece has attempted to shed some light on this issue and serve as a call for additional work in the area. 


\section{Acknowledgements}

This piece was written while the author was on leave from Wellesley College as a visiting fellow at the Brookings Institution; financial support from the Andrew W. Mellon Early Career Fellowship in Economic Studies is gratefully acknowledged. Daniel Theisen provided extremely helpful research assistance. Bill Evans, Maeve Gearing, and Jonathan Rork provided helpful suggestions.

\section{References}

Alm, James, Michael McKee, and Mark Skidmore. 1993. "Fiscal Pressure, Tax Competition, and the Introduction of State Lotteries.” National Tax Journal 46, No. 4: 463-76.

Anders, Gary C., Donald Siegel and Munther Yacoub. 1998. "Does Indian casino gambling reduce state revenues? Evidence from Arizona," Contemporary Economic Policy 16, No. 3 (July): 347-356

Berry, Frances S. and William D. Berry. 1990. "State Lottery Adoptions as Policy Innovations: An Event History Analysis,” American Political Science Review 84 No. 2 (June): 395-415.

Borg, Mary O., Paul M. Mason, and Stephen L. Shapiro. 1991. The economic consequences of state lotteries. Westport, Connecticut: Greenwood Publishing Group.

Borg, Mary O. and Paul M. Mason. 1990. "Earmarked Lottery Revenues: Positive Windfalls or Concealed Redistribution Mechanisms?” Journal of Education Finance 15 (Fall): 289-301.

— 1988. "The Budgetary Incidence of a Lottery to Support Education,” National Tax Journal 41 No. 1: 75-85.

Brown, Ryan P. and Jonathan C. Rork. Forthcoming. "Copycat Gaming: A Spatial Analysis of State Lottery Structure”. Regional Science and Urban Economics.

Christiansen Capital Advisors. 2004. “Gross Annual Wager of the United States 2004”, summarized in International Gaming and Wagering Business 25 No. 9 (September): 1, 60-61.

Clotfelter, Charles T., Philip J. Cook, Julie A. Edell, and Marion Moore. 1999. State Lotteries at the Turn of the Century: Report to the National Gambling Impact Study Commission. Duke University. 
Clotfelter, Charles T. and Philip J. Cook. 1993. “The 'Gambler’s Fallacy’ in Lottery Play,” Management Science 39 No. 12 (December): 1521-1525.

- 1989. Selling Hope: State Lotteries in America. Cambridge, MA: Harvard University Press.

ComScore Networks. 2002. "High Rollers Take Note: Online Casinos are Serious About Luring You In, Reports Jupiter Media Metrix,” http://www.comscore.com/press/release.asp?id=272.

Eadington, William R. 1999. “The economics of casino gambling.” Journal of Economic Perspectives 13 No. 3 (August): 173-192.

Elliott, Donald S. and John C. Navin. 2002. "Has Riverboat Gambling Reduced State Lottery Revenue?” Public Finance Review 30 No. 3 (May): 235-247.

Evans, William and Ping Zhang. 2003. "The Impact of Earmarked Lottery Revenue on State Educational Expenditures.” University of Maryland mimeo. July.

Evans, William and Julie Topoleski. 2002. "The Social and Economic Impact of Native American Casinos.” NBER Working Paper No. 9198. Cambridge, MA: National Bureau of Economic Research.

Fink, Stephen C., and Jonathan C. Rork. 2003. "The Importance of Self-Selection in Casino Cannibalization of State Lotteries,” Economics Bulletin 8 No. 10 (September): 1-8.

Fink, Stephen C., Alan C. Marco, and Jonathan C. Rork. 2004. "Lotto Nothing? The Budgetary Impact of State Lotteries,” Applied Economics 36 No. 21(December): 2357-2367.

Garrett, Thomas A. and Thomas L. Marsh. 2002. "The Revenue Impacts of Cross-Border Lottery Shopping in the Presence of Spatial Autocorrelation,” Regional Science and Urban Economics 32 No. 4 (July): 501-519.

Gerstein, Dean, John Hoffman, Cindy Larison, Laszlo Engelman, Sally Murphy, Amanda Palmer, Lucian Chuchro, Marianna Toce, Robert Johnson, Tracy Bule, and Mary Ann Hill. 1999. Gambling Impact and Behavior Study: Report to the National Gambling Impact Study Commission. Chicago, IL: National Opinion Research Center at the University of Chicago.

Grinols, Earl L. and David B. Mustard. 2004. Casinos, Crime, and Community Costs. University of Illinois and University of Georgia working paper.

Guryan, Jonathan and Melissa S. Kearney. 2005. "Perceptions of Randomness and Habit Formation among Lottery Gamblers.” University of Chicago, GSB mimeo. 
Hahn, Robert W. and Paul C. Tetlock. 2004. “A New Approach for Regulating Information Markets,” AEI-Brookings Joint Center for Regulatory Studies.

Hansen, Ann. 1995. “The Tax Incidence of the Colorado State Lottery Instant Game”. Public Finance Quarterly 23 No. 3 (July): 385-99.

Imbens, Guido W., Donald B. Rubin, and Bruce Sacerdote. 2001. "Estimating the Effect of Unearned Income on Labor Supply, Earnings, Savings, and Consumption: Evidence from a Survey of Lottery Players.” American Economic Review 91 No. 4 (September): 778-794.

Jones, Jeffrey. 2004. “Gambling a Common Activity for Americans,” The Gallup Organization. March 24. http://www.gallup.com/poll. Accessed 11/1/2004.

Kearney, Melissa S. forthcoming. "State Lotteries and Consumer Behavior.” Journal of Public Economics.

LaFleur, Terri. 2003. LaFleur’s Magazine 1(1) (September): 13-25. www.lafleurs.com.

Meister, Alan. 2004. Indian Gaming Industry Report: 2004-2005. Analysis Group, Inc. Newton, MA: Casino City Press.

Mikesell, John and C. Kurt Zorn. 1986. "State Lotteries as Fiscal Savior or Fiscal Fraud: A Look at the Evidence,” Public Administration Review 46 (July/August): 311320.

Miyazaki, A., A. Hansen, and D. Sprott. 1998. “A Longitudinal Analysis of IncomeBased Tax Regressivity of State-Sponsored Lotteries,” Journal of Public Policy and Marketing 17 No. 2: 161-172.

National Gambling Impact Study Commission. 1999. Final Report.

Novarro, Neva. 2002. "Does Earmarking Matter? The Case of State Lottery Profits and Educational Spending.” SIEPR Dicussion Paper No. 02-19

Oster, Emily. 2004. “Are All Lotteries Regressive? Evidence from the Powerball.” National Tax Journal 57: 179-87.

Popp, Anthony V. and Charles Stehwien. 2002. "Indian Casino Gambling and State Revenue: Some Further Evidence,” Public Finance Review 30 No. 4 (July): 320330.

Scott, Frank and John Garen. 1994. "Probability of purchase, amount of purchase, and the demographic incidence of the lottery tax,” Journal of Public Economics 54 (May): 121-143. 
Siegel, Donald and Gary Anders. 1999. Public policy and the displacement effects of casinos: A case study of riverboat gambling in Missouri. Journal of Gambling Studies 15 No. 2 (Summer): 105-21.

— 2001. "The Impact of Indian Casinos on State Lotteries: A Case Study of Arizona,” Public Finance Review 29 No. 2 (March): 139-47.

Spindler, Charles J. 1995. "The Lottery and Education: Robbing Peter to Pay Paul?" Public Budgeting and Finance 15 (Fall): 54-62.

Stranahan, Harriet A. and Mary O. Borg. 2004. "Some Futures are Brighter than Others: The Net Benefits Received by Florida Bright Futures Scholarship Recipients,” Public Finance Review 31 No. 1 (January): 105-126.

Taylor, Jonathan B., Matthew B. Krepps, and Patrick Wang. 2000. “The National Evidence on the Socioeconomic Impacts of American Indian Gaming on NonIndian Communities," Harvard Project on American Indian Development, Working Paper 00-1 (April).

Terrell, Dek. 1994. “A Test of the Gambler’s Fallacy - Evidence from Pari-Mutuel Games,” Journal of Risk and Uncertainty 8 No. 3: 309-317.

Thompson, William N., and Robert Schmidt. 2002. "Not Exactly 'A Fair Share’: Revenue Sharing and Native American Casinos in Wisconsin,” Wisconsin Policy Research Institute Report 15 No. 1: 1-25.

Tosun, Mehmet Serken and Mark Skidmore. 2004. “Interstate Competition and State Lottery Revenue,” National Tax Journal 72 No. 2: 163-178.

United States General Accounting Office. 2002. Internet Gambling: An Overview of the Issues. http://www.gao.gov/new.items/d0389.pdf.

- 2000. Impact of Gambling: Economic Effects More Measurable than Social Effects. April. http://www.gao.gov/new.items/gg00078.pdf.

United States Census Bureau. 2004. 2001 Survey of Government Finances. March.

Worthington, Andrew C. 2001. "Implicit Finance in Gambling Expenditures: Australian Evidence on Socioeconomic and Demographic Tax Incidence," Public Finance Review 29 No. 4 (July): 326-342. 
Figure 1: 2003 Gross Gambling Revenues by Industry (\$ Billions)

\section{Total: \$78.6 billion}

Internet gambling, 7.2\%

Charitable games, $2.0 \%$ Charitable bingo, $1.4 \%$

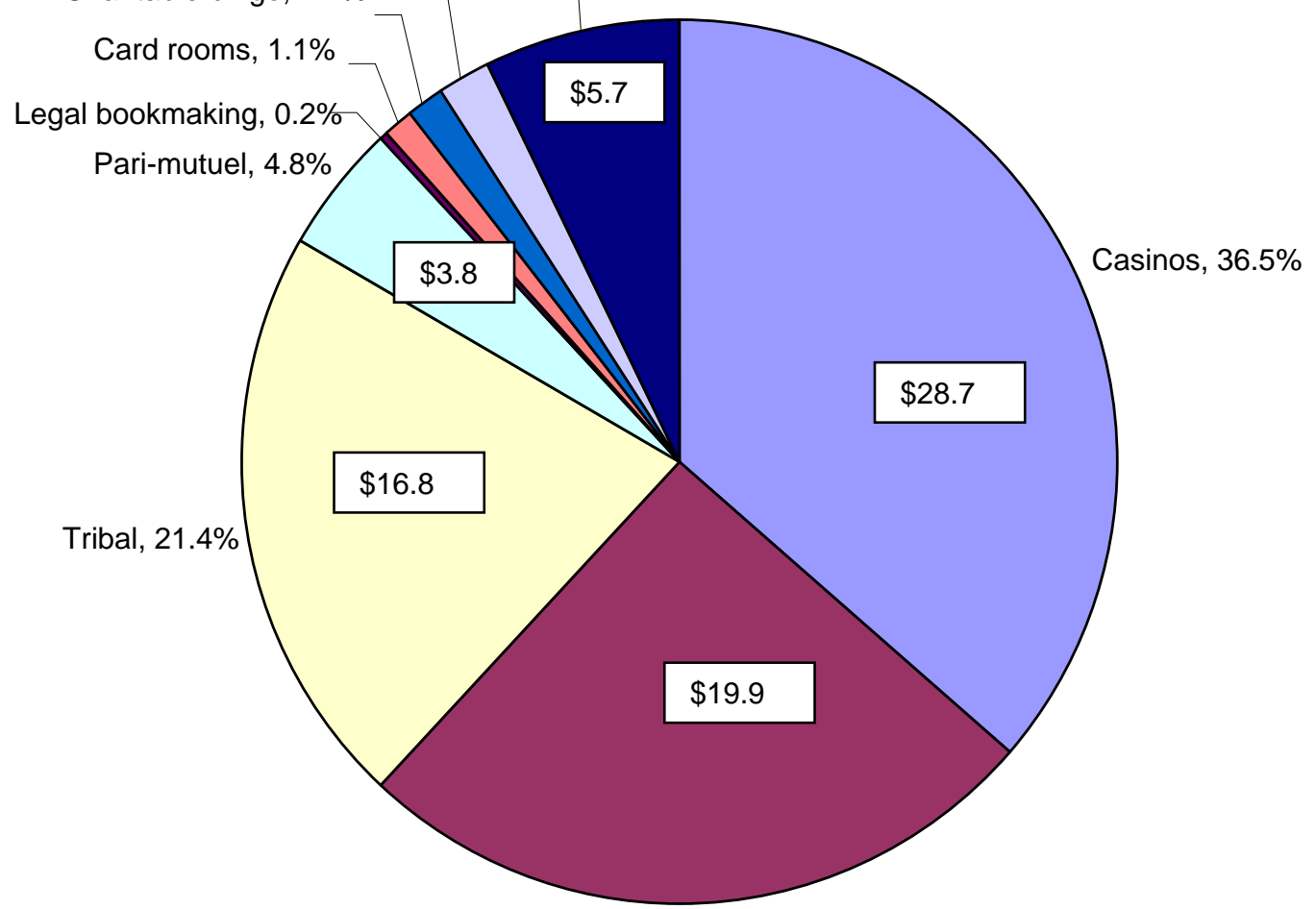

State Lotteries, $25.4 \%$

Source: Christiansen Capital Advisors (2004) 


\section{Figure 2: Participation in Forms of Gambling Over the Past 12 Months}

Gallup Lifestyle Poll, December 11-14, 2003

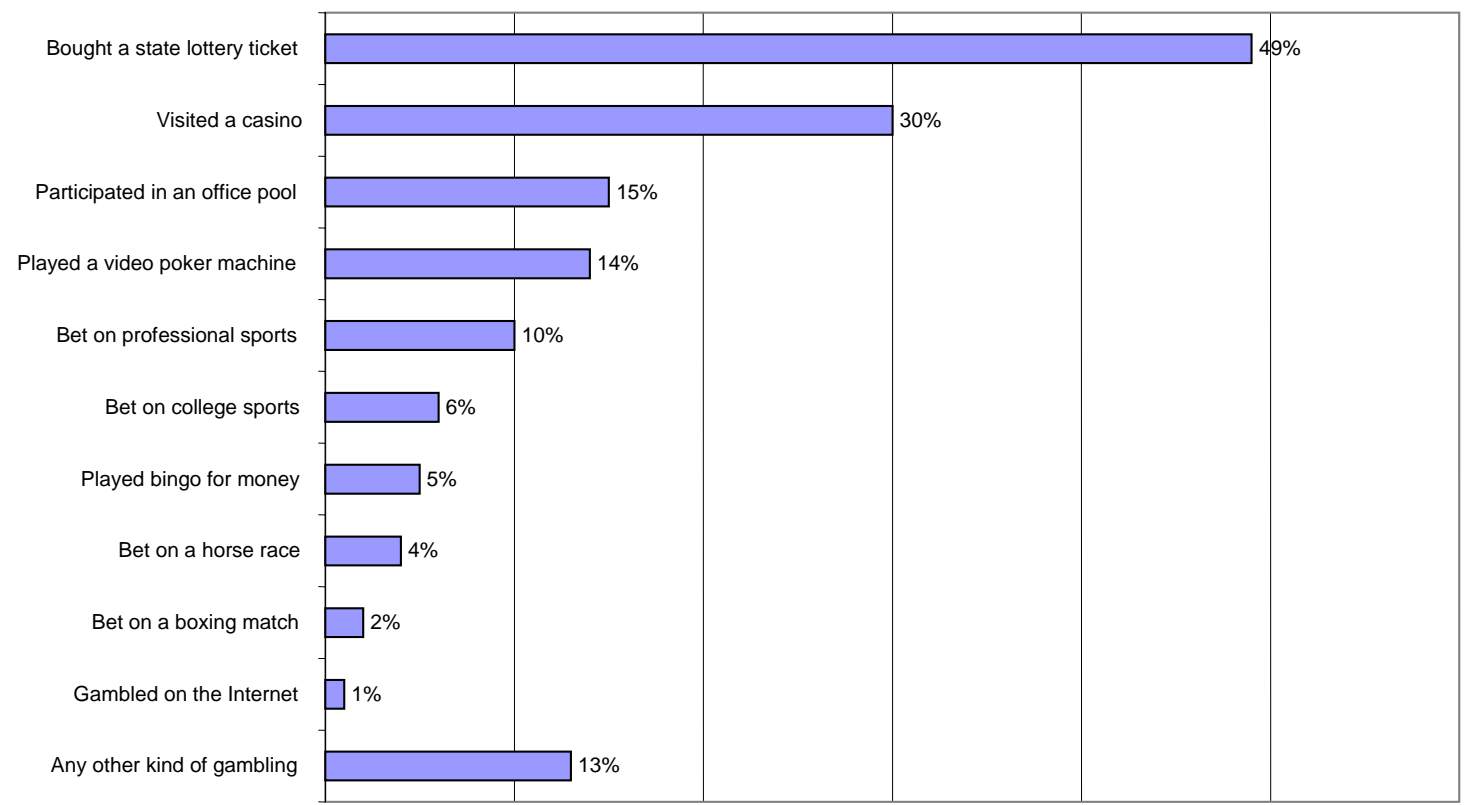

Source: Jones, Jeffrey. 2004. “Gambling a Common Activity for Americans,” The Gallup Organization. March 24. http://www.gallup.com/poll. Accessed 11/1/2004. 
Table 1: Availability of Legalized Gambling, by State

\begin{tabular}{|c|c|c|c|c|c|}
\hline & \multicolumn{2}{|c|}{ State Lottery } & \multirow{2}{*}{$\begin{array}{c}\text { Indian } \\
\text { Casinos } \\
\text { Number of } \\
\text { casinos } \\
(2003)\end{array}$} & \multirow{2}{*}{$\begin{array}{c}\begin{array}{c}\text { Commercial } \\
\text { Casinos }\end{array} \\
\text { Number of } \\
\text { casinos }^{2} \\
(2003)\end{array}$} & \multirow{2}{*}{$\begin{array}{c}\begin{array}{c}\text { Internet } \\
\text { Gambling }\end{array} \\
\text { States expressly } \\
\text { outlawing (year } \\
\text { law enacted) }\end{array}$} \\
\hline State & $\begin{array}{c}\text { Introduction } \\
\text { date of state } \\
\text { lottery }\end{array}$ & $\begin{array}{l}\text { Introduction } \\
\text { date of instant } \\
\text { games }\end{array}$ & & & \\
\hline Alabama & - & - & 3 & & \\
\hline Alaska & - & - & $3^{1}$ & & \\
\hline Arizona & $7 / 81$ & $7 / 81$ & 22 & & \\
\hline Arkansas & - & - & & & \\
\hline California & $10 / 85$ & $2 / 90$ & 56 & & \\
\hline Colorado & $1 / 83$ & $10 / 84$ & 2 & 40 & \\
\hline Connecticut & $2 / 72$ & $9 / 95$ & 2 & & \\
\hline Delaware & $10 / 75$ & $2 / 76$ & & 1 & \\
\hline D.C. & $8 / 82$ & $8 / 82$ & & & \\
\hline Florida & $1 / 88$ & $1 / 88$ & 6 & & \\
\hline Georgia & $6 / 93$ & $6 / 93$ & & & \\
\hline Hawaii & - & - & & & \\
\hline Idaho & $7 / 89$ & $7 / 89$ & 6 & & \\
\hline Illinois & $6 / 74$ & $10 / 75$ & & 9 & Yes (1999) \\
\hline Indiana & $10 / 89$ & $10 / 89$ & & 9 & \\
\hline Iowa & $8 / 85$ & $8 / 85$ & 2 & 14 & \\
\hline Kansas & $11 / 87$ & $11 / 87$ & 6 & & \\
\hline Kentucky & $4 / 89$ & $4 / 89$ & & & \\
\hline Louisiana & $9 / 91$ & $9 / 91$ & 3 & 13 & Yes (1997) \\
\hline Maine & $6 / 74$ & $1 / 75$ & 1 & & \\
\hline Maryland & $5 / 73$ & $2 / 76$ & & & \\
\hline Massachusetts & $3 / 72$ & $5 / 74$ & & & \\
\hline Michigan & $11 / 72$ & $10 / 75$ & 16 & 3 & Yes (1999) \\
\hline Minnesota & $4 / 90$ & $4 / 90$ & 19 & & \\
\hline Mississippi & - & - & 2 & 29 & \\
\hline Missouri & $1 / 86$ & $1 / 86$ & & 10 & \\
\hline Montana & $6 / 87$ & $6 / 87$ & 25 & & \\
\hline Nebraska & $9 / 93$ & 9/93 & 1 & & \\
\hline Nevada & - & - & 3 & 224 & Yes (1997) \\
\hline New Hampshire & $3 / 64$ & $5 / 96$ & & & \\
\hline New Jersey & $12 / 70$ & $6 / 75$ & & 13 & \\
\hline New Mexico & $4 / 96$ & $4 / 96$ & 19 & 1 & \\
\hline New York & $6 / 67$ & $1 / 76$ & 6 & & \\
\hline North Carolina & - & - & 2 & & \\
\hline North Dakota & $3 / 04$ & - & 5 & & \\
\hline Ohio & $8 / 74$ & $6 / 76$ & & & \\
\hline Oklahoma & - & - & 73 & & \\
\hline Oregon & $4 / 85$ & $4 / 85$ & 8 & & Yes (2001) \\
\hline Pennsylvania & $3 / 72$ & $5 / 75$ & & & \\
\hline Rhode Island & $5 / 74$ & $5 / 76$ & & 2 & \\
\hline South Carolina & $1 / 02$ & $1 / 02$ & 1 & & \\
\hline South Dakota & $9 / 87$ & $9 / 87$ & 12 & 19 & Yes (2000) \\
\hline Tennessee & $1 / 04$ & $1 / 04$ & & & \\
\hline Texas & $5 / 92$ & $5 / 92$ & 1 & & \\
\hline Utah & - & - & & & (gambling illegal) \\
\hline Vermont & $2 / 78$ & $6 / 78$ & & & \\
\hline Virginia & $9 / 88$ & $9 / 88$ & & & \\
\hline Washington & $11 / 82$ & $11 / 82$ & 28 & & \\
\hline West Virginia & $1 / 86$ & $6 / 86$ & & 4 & \\
\hline Wisconsin & $9 / 88$ & $9 / 88$ & 22 & & \\
\hline Wyoming & - & - & 1 & & \\
\hline Total & & & 356 & 391 & \\
\hline
\end{tabular}

Sources: State lottery dates reproduced from Kearney (forthcoming); Indian Casino data from Meister (2004); Commerical casino data from http://www.gamblinganswers.com/casinos/country/us/ (Accessed on 1/19/05) and Christiansen Capital 
Advisors, LLL http://www.cca-i.com (Accessed on 1/19/05). Internet gambling data from American Gaming Association http://www.americangaming.org/Industry/factsheets/issues_detail.cfv?id=17 (Accessed on 1/19/05).

Notes:

1. Number of tribes does not include the Native Villages that conducted gaming activities as non-profit organizations (60 in 2003).

2. Includes traditional casinos and riverboats, as well as racinos (racetrack casinos).

Table 2: 2003 Revenues Generated by Gaming Type (\$ Millions)

\begin{tabular}{|c|c|c|c|c|c|}
\hline \multirow[b]{2}{*}{ State } & \multicolumn{2}{|c|}{ State Lottery } & \multirow{2}{*}{$\begin{array}{c}\begin{array}{c}\text { Traditional } \\
\text { Casinos }\end{array} \\
\\
\text { Revenue from } \\
\text { casinos }^{2}\end{array}$} & \multicolumn{2}{|c|}{ Indian Casinos } \\
\hline & $\begin{array}{l}\text { Revenue } \\
\text { from state } \\
\text { lottery }^{1}\end{array}$ & $\begin{array}{l}\text { Revenue } \\
\text { from instant } \\
\text { games }\end{array}$ & & $\begin{array}{l}\text { Revenue from } \\
\text { casinos }^{3}\end{array}$ & $\begin{array}{c}\text { Tribal } \\
\text { Contributions to } \\
\text { State and Local } \\
\text { Governments }\end{array}$ \\
\hline \multicolumn{6}{|l|}{ Alabama } \\
\hline Alaska & & & & 8.4 & $\$ 0.3^{4}$ \\
\hline Arizona & 322.3 & 159.2 & & $1,218.3$ & 42.9 \\
\hline \multicolumn{6}{|l|}{ Arkansas } \\
\hline California & $2,764.3$ & $1,193.0$ & & $4,225.8$ & 131.6 \\
\hline Colorado & 391.5 & $2,54.3$ & 698.3 & 55.2 & \\
\hline Connecticut & 865.3 & 530.7 & & $2,022.6$ & 396.4 \\
\hline Delaware & 628.1 & 22.3 & 502.0 & & \\
\hline D.C. & 228.9 & 36.1 & & & \\
\hline Florida & $2,920.6$ & $1,126.4$ & & 683.4 & \\
\hline Georgia & $2,604.4$ & $1,486.2$ & & & \\
\hline \multicolumn{6}{|l|}{ Hawaii } \\
\hline Idaho & 98.3 & 60.9 & 330.3 & 119.0 & $4.8^{4}$ \\
\hline Illinois & $1,585.8$ & 697.9 & $1,709.3$ & & \\
\hline Indiana & 665.6 & 386.2 & $2,229.9$ & & \\
\hline Iowa & 187.8 & 84.9 & 694.3 & & \\
\hline Kansas & 210.8 & 86.6 & & 170.4 & \\
\hline Kentucky & 673.5 & 319.9 & & & \\
\hline Louisiana & 311.6 & 102.5 & $2,017.4$ & 493.8 & 10.2 \\
\hline Maine & 164.6 & 124.9 & & & $0.1^{5}$ \\
\hline Maryland & $1,322.4$ & 315.9 & & & \\
\hline Massachusetts & $4,197.8$ & $2,891.7$ & & & \\
\hline Michigan & $1,697.9$ & 681.8 & $1,130.2$ & 870.6 & 31.5 \\
\hline Minnesota & 351.7 & 210.9 & & $1,385.7$ & $16.1^{4}$ \\
\hline Mississippi & & & $2,701.3$ & & \\
\hline Missouri & 718.2 & 403.8 & $1,331.7$ & & \\
\hline Montana & 34.7 & 10.1 & & 14.9 & \\
\hline Nebraska & 80.9 & 40.5 & & & \\
\hline Nevada & & & $9,625.3$ & 44.0 & \\
\hline New Hampshire & 221.3 & 151.0 & & & \\
\hline New Jersey & $2,075.7$ & 901.2 & $4,488.5$ & & \\
\hline New Mexico & 137.0 & 80.2 & 154.4 & 610.7 & 36.9 \\
\hline New York & $5,413.1$ & $2,412.0$ & & 549.2 & \\
\hline \multicolumn{6}{|l|}{ North Carolina } \\
\hline North Dakota & & & & 95.0 & \\
\hline Ohio & $2,069.1$ & $1,077.8$ & & & \\
\hline Oklahoma & & & & 465.9 & \\
\hline Oregon & 853.2 & 133.0 & & 426.1 & 8.8 \\
\hline Pennsylvania & 2133.0 & 796.6 & & & \\
\hline Rhode Island & 554.0 & 75.8 & 333.5 & & \\
\hline South Carolina & 722.4 & 422.9 & & & 1.0 \\
\hline South Dakota & 647.0 & 13.3 & 70.4 & 50.0 & \\
\hline \multicolumn{6}{|l|}{ Tennessee } \\
\hline Texas & $3,149.6$ & $2,148.0$ & & & \\
\hline \multicolumn{6}{|l|}{ Utah } \\
\hline Vermont & 79.7 & 67.2 & & & \\
\hline
\end{tabular}




\begin{tabular}{|l|l|l|l|l|l|}
\hline Virginia & $1,135.7$ & 543.4 & & & \\
\hline Washington & 460.4 & 241.9 & & 769.5 & $2.9^{4}$ \\
\hline West Virginia & $1,081.9$ & 105.4 & 781.5 & & \\
\hline Wisconsin & 435.1 & 245.2 & & $1,077.9$ & 32.0 \\
\hline Wyoming & & & & & \\
\hline Total & $\mathbf{\$ 4 4 , 1 9 4 . 9}$ & $\mathbf{\$ 2 0 , 6 4 1 . 9}$ & $\mathbf{\$ 2 8 , 7 9 8 . 1}$ & $\mathbf{\$ 1 6 , 2 4 9 . 8}$ & $\mathbf{\$ 7 5 9 . 4}$ \\
\hline
\end{tabular}

Sources: State lottery data from LaFleur’s magazine Vol. 11 Sept 2003. Indian casino and commercial casino data from Meister (2004).

Notes:

1. Includes revenue from all games, including instant games.

2. Alabama, Iowa, Maine, Mississippi, Nebraska, North Carolina, South Carolina, Texas, and Wyoming account for $\$ 893.3$ million in revenues.

3. Includes traditional casinos and riverboats, as well as racinos (racetrack casinos).

4. Incomplete data. Missing years are estimated to be equal to previous year's amount.

5. Annual contribution is a fixed amount. 